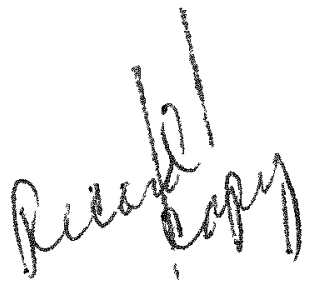

WANL-TME-1036

November 30, 1964

\title{
CONOSEAL BAR-X SEAL TESTS
}

\author{
by \\ J. M. Edmiston \\ Fluid Flow Laboratory \\ Experimental Engineering Department
}

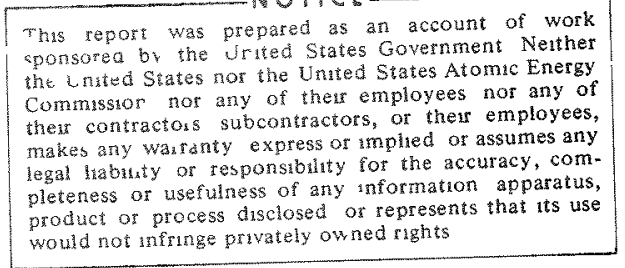

This report was prepared as an account of work the he Lnded Skates nor the Unted States Atom nor any of Comminssior nor any of then employes nor anyees, man contratos subconiractors, ar ansumes any or responsibutsy for th pleteness or usefulness of any ninormatents that its use would aot afronge privately owned rights

Approved by:

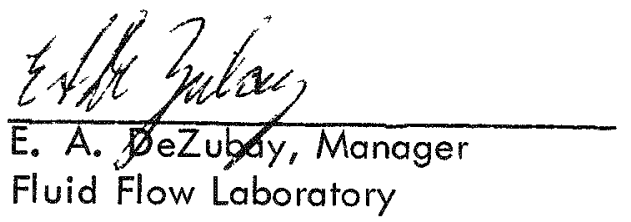

\section{INFORMATION CATEGORY}

UNCLASSIFIED

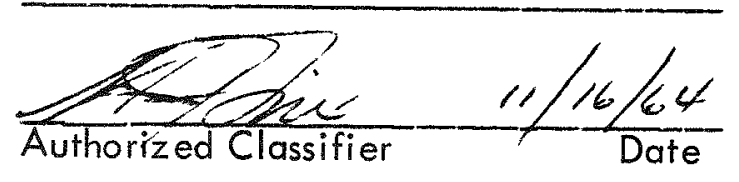




\section{DISCLAIMER}

This report was prepared as an account of work sponsored by an agency of the United States Government. Neither the United States Government nor any agency Thereof, nor any of their employees, makes any warranty, express or implied, or assumes any legal liability or responsibility for the accuracy, completeness, or usefulness of any information, apparatus, product, or process disclosed, or represents that its use would not infringe privately owned rights. Reference herein to any specific commercial product, process, or service by trade name, trademark, manufacturer, or otherwise does not necessarily constitute or imply its endorsement, recommendation, or favoring by the United States Government or any agency thereof. The views and opinions of authors expressed herein do not necessarily state or reflect those of the United States Government or any agency thereof. 


\section{DISCLAIMER}

Portions of this document may be illegible in electronic image products. Images are produced from the best available original document. 


\section{ABSTRACT}

On the NRX-A reactors the instrument ports are sealed by a Bar-X seal. Damage to the ports, which are part of the pressure vessel, required machining on the pressure vessel. A new design, using a Marman flanged piece to house the Bar-X seal port separate from the pressure vessel, was proposed. The test program was to determine the torque required to seal and the ability of each seal to hold during thermal shock.

The Bar-X seal did not leak as in previous test programs, but after cold shock the Marman flange Conoseal gasket sealed marginally at ambient temperature. 
TABLE OF CONTENTS

Page

Abstract

1. Introduction

11. Experimental Equipment

A. Test Fixture

B. Test Method 2

C. Data Obtained 2

III. Calculations 3

IV. Results and Discussion of Their Significance 6

V. Conclusions 7

VI. Recommendations 8

$\begin{array}{ll}\text { Figures } 1 \text { through } 7 & 11 \text { to }\end{array}$

$\begin{array}{ll}\text { Appendix A - Test Record Sheets } & 18\end{array}$

Appendix B - Hardware 
I. INTRODUCTION

These tests are to prove a new sealing configuration that would facilitate repairing damaged sealing surfaces in the instrumentation ports (possibly for NRX-A5).

Previous tests, ${ }^{1,2,3}$ on Bar-X seals in reactor pressure vessel instrument ports, indicated that a Bar-X seal with a maximum loading nut torque of $220 \mathrm{ft}-\mathrm{lb}_{\mathrm{f}}$ will seal adequately. If a seal port is damaged or oversize, and does not seal, the torque may have to be increased to obtain a seal. If it is not possible to seal by increasing the torque, then the port would have to be reworked in the field which is a difficult operation. To overcome this difficult operation, a separate cap has been designed with the port built into it. This seal test fixture is shown in Figure 4 and the Marman flange is shown in Figures 5,6 and 7.

These tests were requested on Reactor Design Work Request Number $41: 41: 55-4 \mathrm{~W}$.

\section{EXPERIMENTAL EQUIPMENT}

A. Test Fixture

The test fixture, as shown on Figures 4 through 7, consists of an aluminum block that represents the pressure vessel and contains half of the Marman flange, a stainless steel cover for the high pressure plenum, a Marman flanged cap containing the instrumentation port, a seal block simulating the instrumentation block, the Marman flange clamp ring, the Bar-X seal nut and the stainless steel, low pressure, cover. The drawings listed in Appendix B describe the fixture in greater detail.

1. WANL-TME-722, "Proof Tests for the Bar-X and K-Seals"

2. WANL-TME-970, "Bar-X Seal Test in Oversize Port"

3. WANL-TME-1035, "Aluminum Bar-X Seal Test" 
B. Test Method

The test flow loop is shown on Figures 1 through 3.

The fixture, less the outlet plenum, was checked with the inlet plenum pressurized with helium and the outlet of the seal covered with water and the appearance of bubbles indicated leakage. The fixture was then installed in the flow loop. After purging with helium, the inlet plenum was pressurized with hydrogen from a gas bottle through a pressure regulator. Leakage was measured by detecting a change in the pressure and the temperature of a fixed volume. This fixed volume included the discharge plenum, the manometer, the pressure gauge, and interconnecting lines. At the completion of the test the hydrogen was vented to atmosphere and the system purged with helium again before disassembly of the test fixture from the loop.

From ambient to stable cryogenic conditions required only immersing the fixture in the liquid nitrogen bath for 25 minutes or until agitation of the nitrogen ceased. Warm-up to room temperature required heating the fixture with hot water or electric heaters. It required at least one hour for the fixture to stabilize at room temperature.

The fixtures with two parallel leakage paths required examination of the Marman flange and Bar-X seal areas by a Vacuum Engineering Company MS-9 mass spectrometer leak detector. With the fixture pressurized with helium, a sniffing tube attachment is connected to the leak detector and is used to probe the fixture to locate the precise location of the leak.

\section{Data Obtained}

During the test period a record was made of:

Marman flange clamp ring torque

Bar-X seal nut torque 
Barometric pressure

Test preparation.

The following readings were recorded every 10 minutes for half an hour at each temperature:

Time

Inlet gauge pressure

Outlet gauge pressure

Outlet manometer reading

Ambient temperature

Fixture ambient temperature

Any pertinent notes.

\section{CALCULATIONS}

The established maximum permissible hydrogen leakage rate from the reactor to the surrounding area was previously established as $10^{-2} \mathrm{std} \mathrm{cc} / \mathrm{sec} /$ in of seal diameter. Since this assembly is to be compared to a Bar-X seal assembly in a pressure vessel port; i. e., no Marman flange, the Bar-X seal leakage allowance would control. For this seal the figure would be $2.020 \times 10^{-2} \mathrm{std} \mathrm{cc} / \mathrm{sec}$, based on the Bar-X seal external diameter. It was decided, as in previous tests, the change in pressure in the fixed volume of the outlet plenum, etc., would be measured.

The temperature throughout this volume of gas is constant and the leakage rate is small; therefore, the process is isothermal. Here the perfect gas law can be applied:

$$
P V=\frac{m \text { Ro } T}{144 M}
$$


where

$$
\begin{aligned}
& P \quad=\text { static pressure in (psia) } \\
& V=\text { volume in } \mathrm{ft}^{3} \\
& \mathrm{~m}=\text { mass }\left(\mathrm{lb}_{\mathrm{m}}\right) \text { in volume } \mathrm{V} \\
& \text { Ro }=\text { universal gas constant is } 1545 \frac{\mathrm{ft} \mathrm{lb}}{\mathrm{Tb} \text { mole OR }} \\
& M \quad=\text { molecular weight of hydrogen is } 2.016 \mathrm{lb} / \mathrm{m} / \mathrm{lb} \text { mole } \\
& T \quad=\text { temperature in degrees Rankine }
\end{aligned}
$$

but since

$$
m=W t
$$

where

$$
\begin{aligned}
W= & \text { mass flow per unit time }\left(\mathrm{lb}_{\mathrm{m}} / \mathrm{sec}\right) \\
+= & \text { time }(t) \text { required to obtain mass }(\mathrm{m}) \text { for flow rate }(W) \\
& \text { (seconds) }
\end{aligned}
$$

Equation (1) can be written as

$$
P V=\frac{W \text { Ro } T t}{144 M}
$$

or

$$
\left(P_{2}-P_{1}\right) V=\frac{W \text { Ro } T\left(t_{2}-t_{1}\right)}{144 M}
$$

rearranged we get 


$$
\Delta P=\frac{W \operatorname{Ro} T(\Delta t)}{144 M V}
$$

where

$$
\begin{aligned}
& \left(P_{2}-P_{1}\right), \Delta P=\text { maximum allowable pressure rise in the leakage } \\
& \text { plenum }\left(1 b_{f} / \text { in }^{2}\right) \\
& \left(t_{2}-t_{1}\right), \Delta t \quad=\text { period over which the pressure rise is measured } \\
& \text { (seconds) } \\
& V=\text { leakage plenum volume. This includes the volume of the } \\
& \text { pressure lines to gauges and to vent valve }\left(\mathrm{ft}^{3}\right. \text { ) } \\
& M=\text { molecular weight of hydrogen is } 2.016 \mathrm{lb} / \mathrm{m} / \mathrm{b} \text { mole } \\
& \text { Ro = universal gas constant is } 1545 \frac{\mathrm{ft} \mathrm{l}_{\mathrm{f}}}{\mathrm{Tb} \mathrm{bole}^{O_{R}}} \\
& T=\text { temperature in }{ }^{\circ} R \text {, the process is assumed to be isothermal, } \\
& \text { hence the temperature in the seal discharge plenum is assumed } \\
& \text { to be that of the seal inlet plenum which, in turn, is assumed to } \\
& \text { be that of the fluid surrounding the test fixture. The surrounding } \\
& \text { fluid is ambient air or liquid nitrogen. } \\
& W=\text { maximum permissible hydrogen leakage rate }\left(\mathrm{lb}_{\mathrm{m}} / \mathrm{sec}\right)
\end{aligned}
$$

With the use of Equation (3), the maximum allowable pressure rise will be calculated for the cryogenic and ambient temperature cases. The values of the parameters are as follows:

$V$ = the leakage volume of Bar-X seal test fixture is approximately $0.0236 \mathrm{ft}^{3}$

$\mathrm{W}=$ maximum permissible leakage flow based on a 2.020-inch seal diameter $\left(3.740 \times 10^{-9} \mathrm{lb}_{\mathrm{m}} / \mathrm{sec}\right)$ 
Ro $=1545 \frac{\mathrm{ft} \mathrm{lb}_{f}}{1 \mathrm{~b} \text { mole } \mathrm{O}_{\mathrm{R}}}$

$+\quad=$ for one hour test period (3600 seconds)

$\mathrm{T}=140^{\circ} \mathrm{R}$ for cryogenic temperature case

$540^{\circ} \mathrm{R}$ for ambient temperature case

Hence for the cryogenic case, the maximum allowable change in pressure with time is:

$$
\Delta P=0.853^{\prime \prime} \mathrm{Hg} / \mathrm{hr}
$$

(This assumes that the entire measured volume is at $140^{\circ} \mathrm{F}$ and thus is a conservative figure. Most of the volume is at this temperature.)

and for the ambient case, the maximum allowable change in pressure with time is:

$$
\Delta P=3.23^{\prime \prime} \mathrm{Hg} / \mathrm{hr}
$$

\section{RESULTS AND DISCUSSION OF THEIR SIGNIFICANCE}

Refer to Table I for the summary used in this discussion. The initial tests indicated that the two seals did not leak at ambient temperature on the first cycle but that a high leak rate occurred at cryogenic conditions. The higher leak rate of cryogenic conditions is as experienced in the previous tests. $1,2,3$

At this point with parallel seals it was decided to check the leakage source on a mass spectrometer leak detector with a sniffer. The result was that the Bar-X seal did not leak and the Conoseal in the Marman flange did.

1. WANL-TME-722, "Proof Tests for the Bar-X and K-Seals"

2. WANL-TME-970, "Bar-X Seal Test in Oversize Port"

3. WANL-TME-1035, "Aluminum Bar-X Seal Test" 
The Conoseal appeared damaged and was replaced before further testing.

On the next test series the seal leaked less at cryogenic conditions than at ambient temperature contrary to previous tests mentioned above. A recheck on the mass spectrometer leak detector disclosed a bad leak at the Marman flange - so bad that it saturated the leak detector.

It was concluded that the combination of an aluminum Conoseal with a stainless steel Marman flanged cover, with temperature cycling considering the different thermal expansions, would cause the seal to be less effective.

At this time the aluminum Marman flanged cover and a new aluminum Conoseal was incorporated into the test fixture. The results that followed on the next five cycles were that the leak rate was not always greater at ambient temperature than at cryogenic conditions. This would indicate that the Conoseal may have changed its seating during temperature alternations. Leakage exceeded the limit allowable, but by such a small margin that it could possibly be considered an acceptable seal.

\section{CONCLUSIONS}

The Bar-X seal is satisfactory, but the use of a parallel seal could not better the sealability of the Bar-X seal by itself.

The aluminum Conoseal in good condition with either an aluminum or stainless steel Marman flanged cover can seal within specifications if considered by itself. A less adequate Bar $-X$ seal coupled with the same Conoseal might not leak within the allowable value if compared with a $\mathrm{Bar}-\mathrm{X}$ seal in a reactor pressure vessel port. If in compromise, an additional leakage allowance is made for the Marman flange then the allowable leakage rate would perhaps be high enough to make the combination acceptable.

The condition of the aluminum Conoseal on disassembly indicate that they could not be used more than once. 


\section{RECOMMENDATIONS}

Consideration could be given to the use of stainless steel Conoseals particularly with a stainless steel Marman flanged cover to permit repeated assembly.

The Marman flange clamping ring is of a light weight spring-type material that will yield enough at higher pressure differentials to permit leakage through the seal. It is recommended that a heavier walled clamping ring be employed in this application; the heavier ring would resist spreading of the clamped flanges, and prohibit leakage. 
TABLE I

CONOSEAL BAR-X SEAL TESTING SUMMARY

\begin{tabular}{|c|c|c|c|c|c|}
\hline Test Description & Gas & $\begin{array}{l}\text { ar }-X \text { Seal } \\
\text { Torque } \\
f t-1 b\end{array}$ & Temperature & $\begin{array}{l}\text { Inlet } \\
\text { Pressure } \\
\text { psig }\end{array}$ & Remarks \\
\hline \multicolumn{6}{|c|}{ Stainless Steel Marman Flange } \\
\hline $\begin{array}{l}\text { * Leak Check With } \\
\text { Water Covering } \\
\text { Outlet Plenum }\end{array}$ & Helium & $\begin{array}{l}120 \\
160 \\
175\end{array}$ & $\begin{array}{l}\text { Ambient } \\
\text { Ambient } \\
\text { Ambient }\end{array}$ & $\begin{array}{l}250 \\
775 \\
806\end{array}$ & $\begin{array}{l}\text { High leak rate. } \\
\text { No leak for } 10 \text { minutes. } \\
\text { No leak. }\end{array}$ \\
\hline Cold Shock & ---- & 175 & Cryogenic & 0 & Preparation for test. \\
\hline Flow Test & $\begin{array}{l}\text { Hydrogen } \\
\text { Hydrogen }\end{array}$ & $\begin{array}{l}175 \\
175\end{array}$ & $\begin{array}{l}\text { Ambient } \\
\text { Cryogenic }\end{array}$ & $\begin{array}{l}720 \\
720\end{array}$ & $\begin{array}{l}\text { No leak for } 30 \text { minutes. } \\
\text { Leak rate } 1.2 \text { times } \\
\text { allowable value on last } \\
10 \text { minutes of } 30 \text { minute } \\
\text { test and increasing. }\end{array}$ \\
\hline Leak Check & Helium & 175 & Ambient & 800 & No leak for 10 minutes. \\
\hline $\begin{array}{l}\text { Leak Check on Mass } \\
\text { Spectrometer Leak } \\
\text { Detector MS-9 }\end{array}$ & Helium & 175 & Cryogenic & 600 & $\begin{array}{l}\text { Leakage around Marman } \\
\text { flange. Bar-X seal did } \\
\text { not leak. Conoseal in- } \\
\text { spected and replaced. }\end{array}$ \\
\hline Leak Check & Helium & 175 & Ambient & 800 & No leak for 10 minutes. \\
\hline Cold Shock & $-\cdots$ & 175 & Cryogenic & 0 & Preparation for test. \\
\hline Flow Test & Hydrogen & 175 & Ambient & 800 & $\begin{array}{l}\text { Leak rate } 0.186 \text { times } \\
\text { allowable over } 30 \\
\text { minute period. }\end{array}$ \\
\hline Flow Test & Hydrogen & 175 & Cryogenic & 800 & No leak. \\
\hline Flow Test & Hydrogen & 175 & Ambient & 800 & $\begin{array}{l}\text { Leak rate } 0.37 \text { time allow- } \\
\text { able over } 30 \text { minute period. }\end{array}$ \\
\hline
\end{tabular}

* Stainless steel Marman flange cover with $90 \mathrm{in}-1 \mathrm{~b}$ torque on clamp ring. 
TABLE I (CONTINUED)

WANL-TME-1036

\begin{tabular}{llllll} 
Test Description & Gas & $\begin{array}{c}\text { Bar-X Seal } \\
\text { Torque } \\
\mathrm{ft}-\mathrm{lb}\end{array}$ & Temperature & $\begin{array}{c}\text { Pressure } \\
\text { psig }\end{array}$ & Remarks \\
\hline Flow Test & Hydrogen & 175 & Cryogenic & 800 & No leak. \\
Leak Test on MS-9 & Helium & 175 & Ambient & 75 & $\begin{array}{l}\text { Leakage around Marman } \\
\text { flange. }\end{array}$
\end{tabular}

Aluminum Marman Flange

\begin{tabular}{|c|c|c|c|c|c|}
\hline **Cold Shock & --- & 175 & Cryogenic & 0 & --- \\
\hline Flow Test & Hydrogen & 175 & Ambient & 820 & $\begin{array}{l}\text { Leak rate } 0.28 \text { times } \\
\text { allowable. }\end{array}$ \\
\hline Flow Test & Hydrogen & 175 & Cryogenic & 820 & $\begin{array}{l}\text { Leak rate } 0.70 \text { times } \\
\text { allowable. }\end{array}$ \\
\hline Flow Test & Hydrogen & 175 & Ambient & 820 & $\begin{array}{l}\text { Leak rate } 1.08 \text { times } \\
\text { allowable. }\end{array}$ \\
\hline Flow Test & Hydrogen & 175 & Cryogenic & 820 & $\begin{array}{l}\text { Leak rate } 0.35 \text { times } \\
\text { allowable. }\end{array}$ \\
\hline Flow Test & Hydrogen & 175 & Ambient & 820 & $\begin{array}{l}\text { Leak rate } 0.186 \text { times } \\
\text { allowable. }\end{array}$ \\
\hline Flow Test & Hydrogen & 175 & Cryogenic & 840 & No leak in 30 minutes. \\
\hline Flow Test & Hydrogen & 175 & Ambient & 810 & $\begin{array}{l}\text { Leak rate } 0.57 \text { times } \\
\text { allowable. }\end{array}$ \\
\hline Flow Test & Hydrogen & 175 & Cryogenic & 825 & $\begin{array}{l}\text { Leak rate } 1.05 \text { times } \\
\text { allowable. }\end{array}$ \\
\hline Flow Test & Hydrogen & 175 & Ambient & 815 & $\begin{array}{l}\text { Leak rate } 0.124 \text { times } \\
\text { allowable. }\end{array}$ \\
\hline Flow Test & Hydrogen & 175 & Cryogenic & 830 & $\begin{array}{l}\text { Leak rate } 0.47 \text { times } \\
\text { allowable. }\end{array}$ \\
\hline Leak Check on MS-9 & Helium & 175 & Ambient & 200 & $\begin{array}{l}\text { Leakage around Marman } \\
\text { flange. }\end{array}$ \\
\hline
\end{tabular}

**Replaced steel flange with aluminum flange with $90 \mathrm{in}-\mathrm{lb}$ torque on clamp ring. 


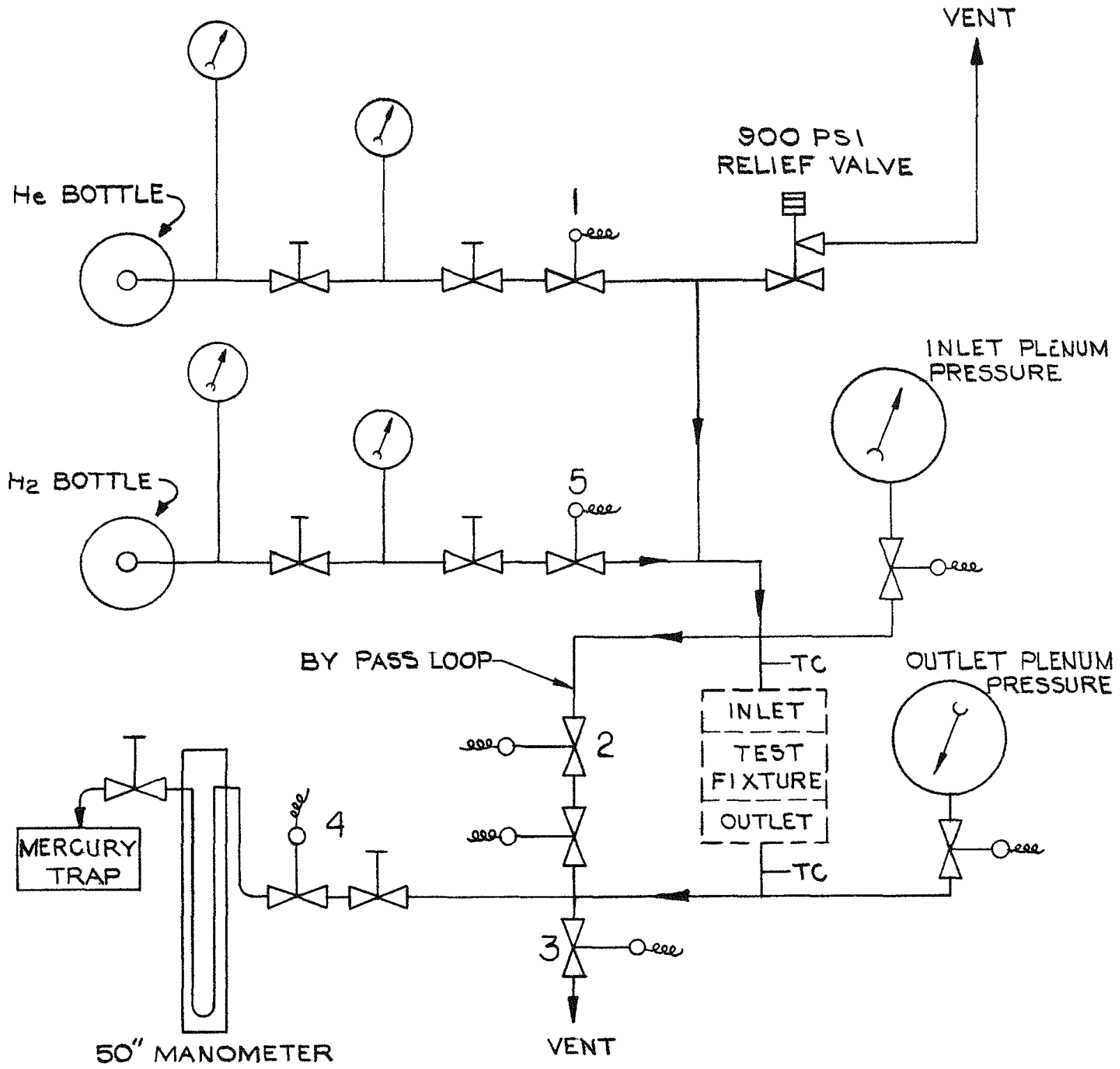

Figure 1

Schematic of Seal Test Facility 
WANL-TME-1036

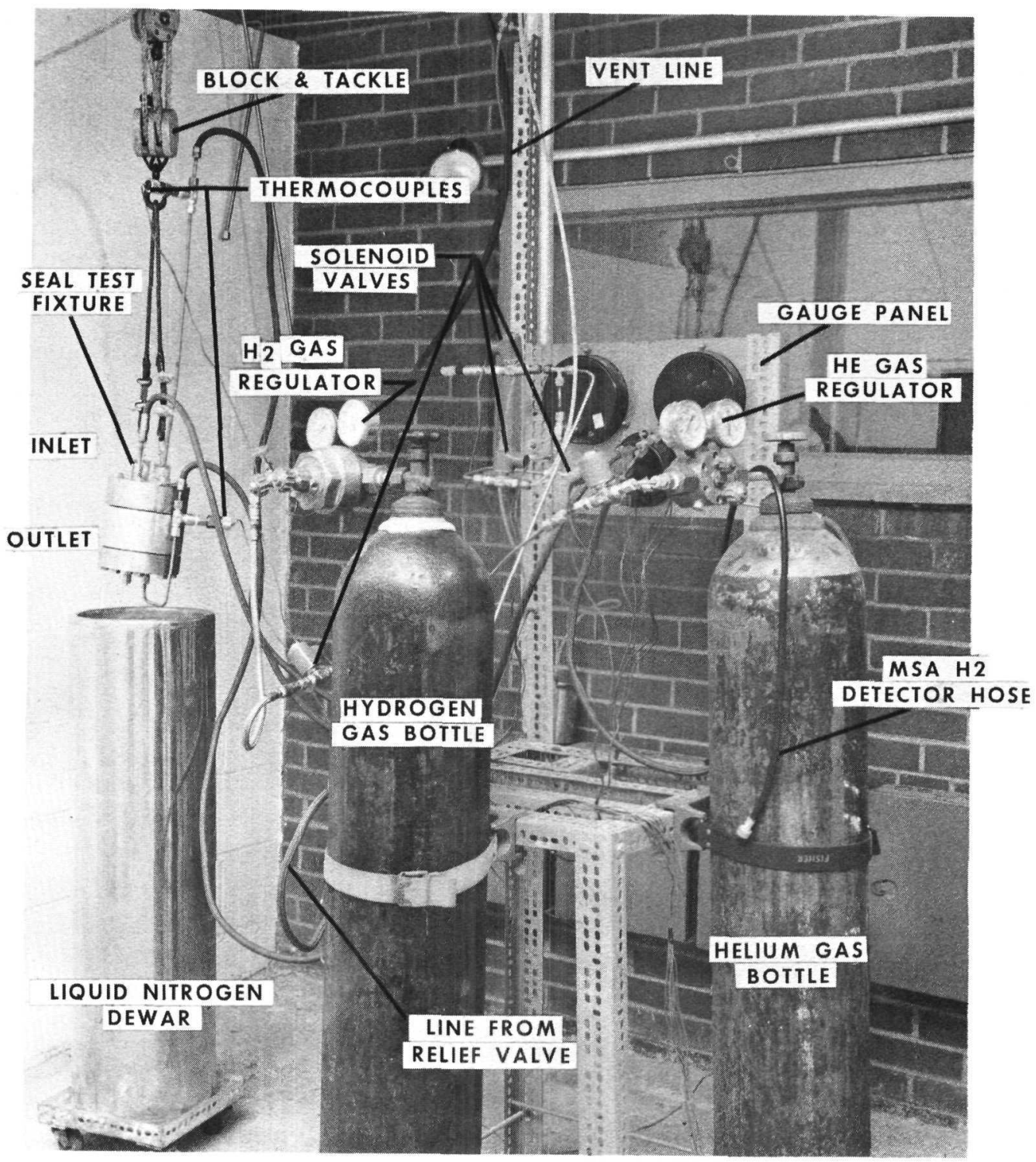

Figure 2

Bar-X Seal Test Arrangement From Interior of Cell 
WANL-TME-1036

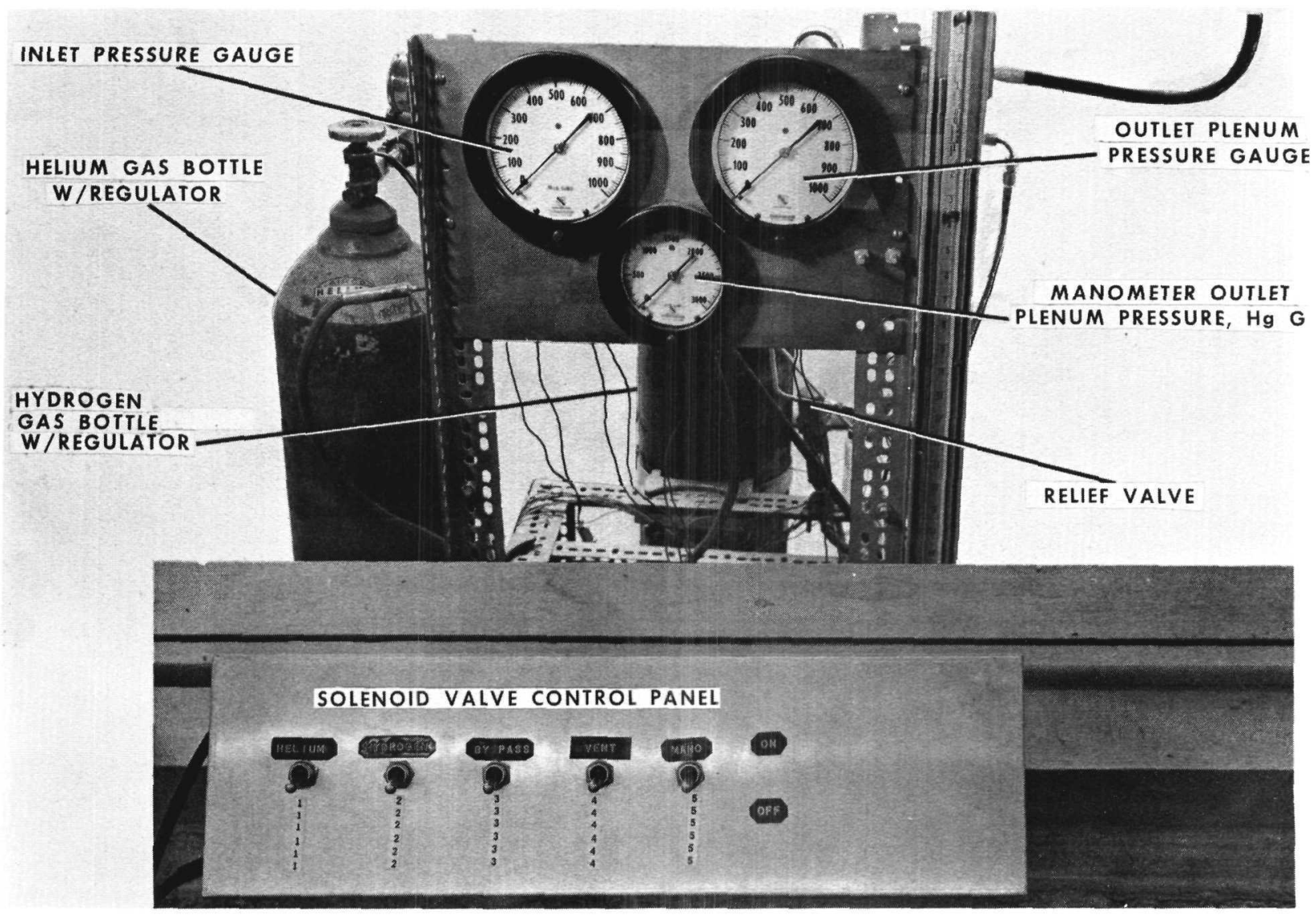

Figure 3

Bar-X Seal Test Arrangement Through Cell Window 


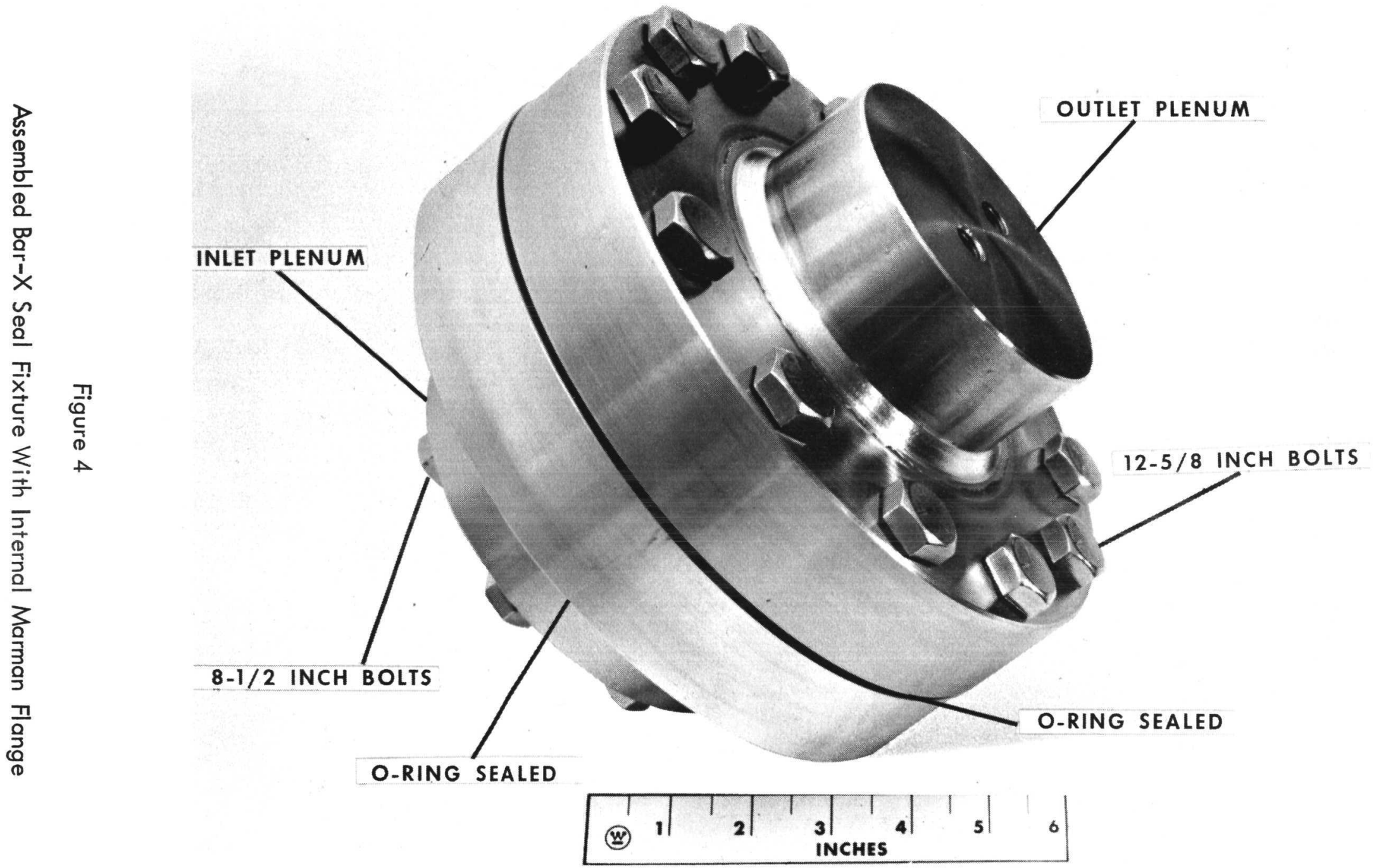

$\vec{A}$

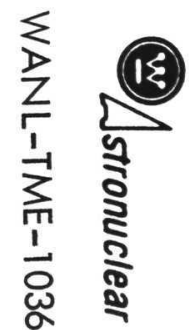




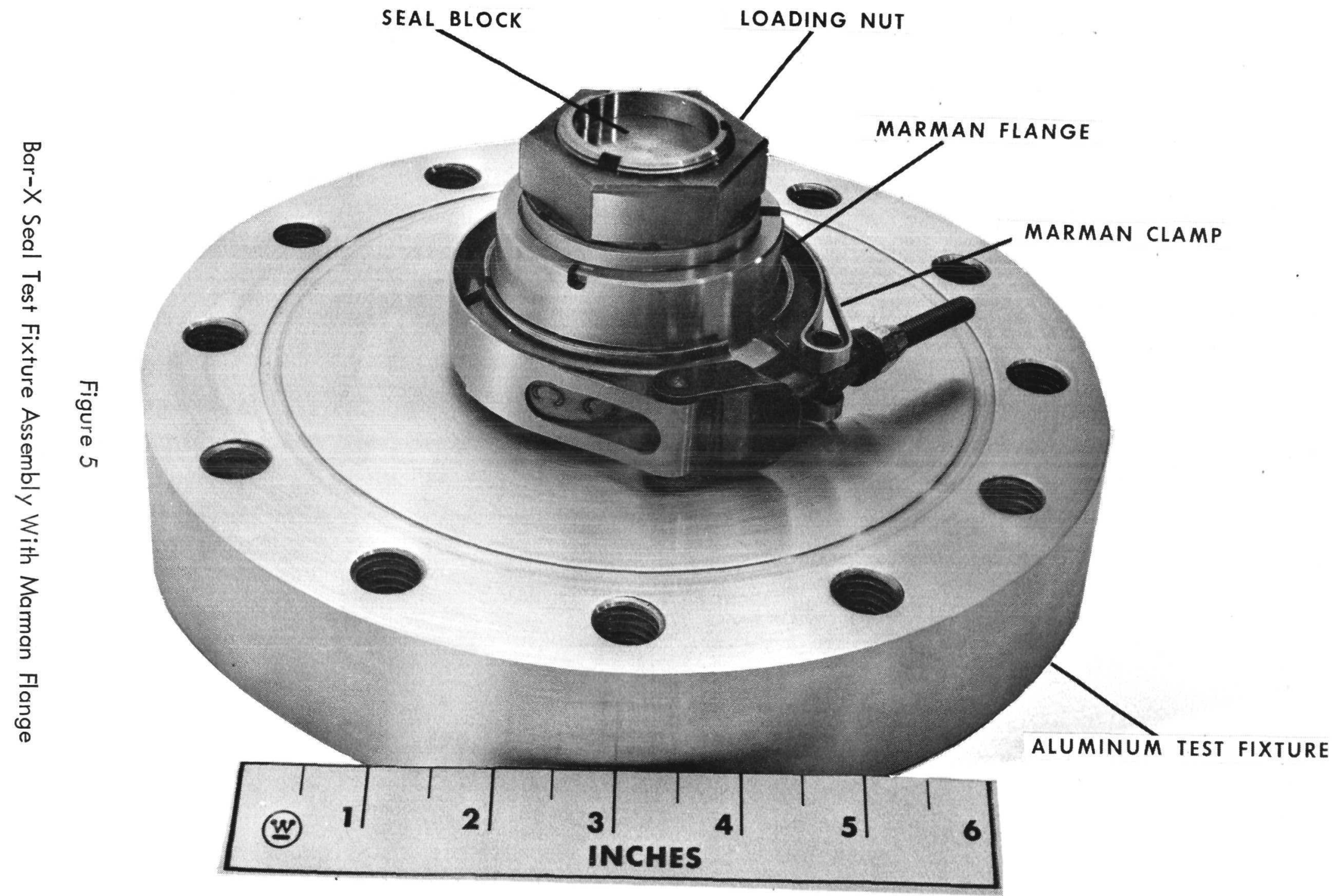




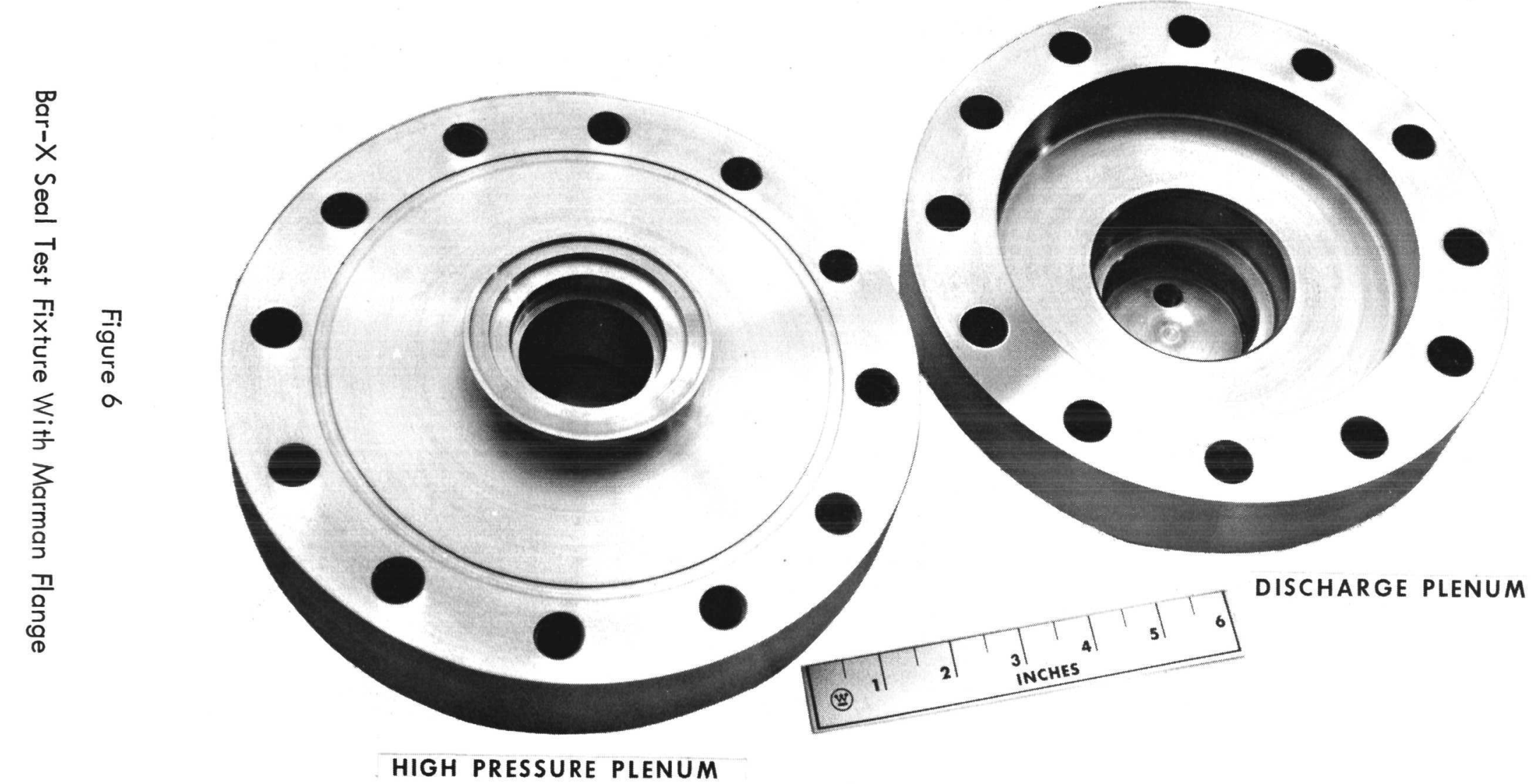




\section{(w) Stronuclear}

WANL-TME-1036

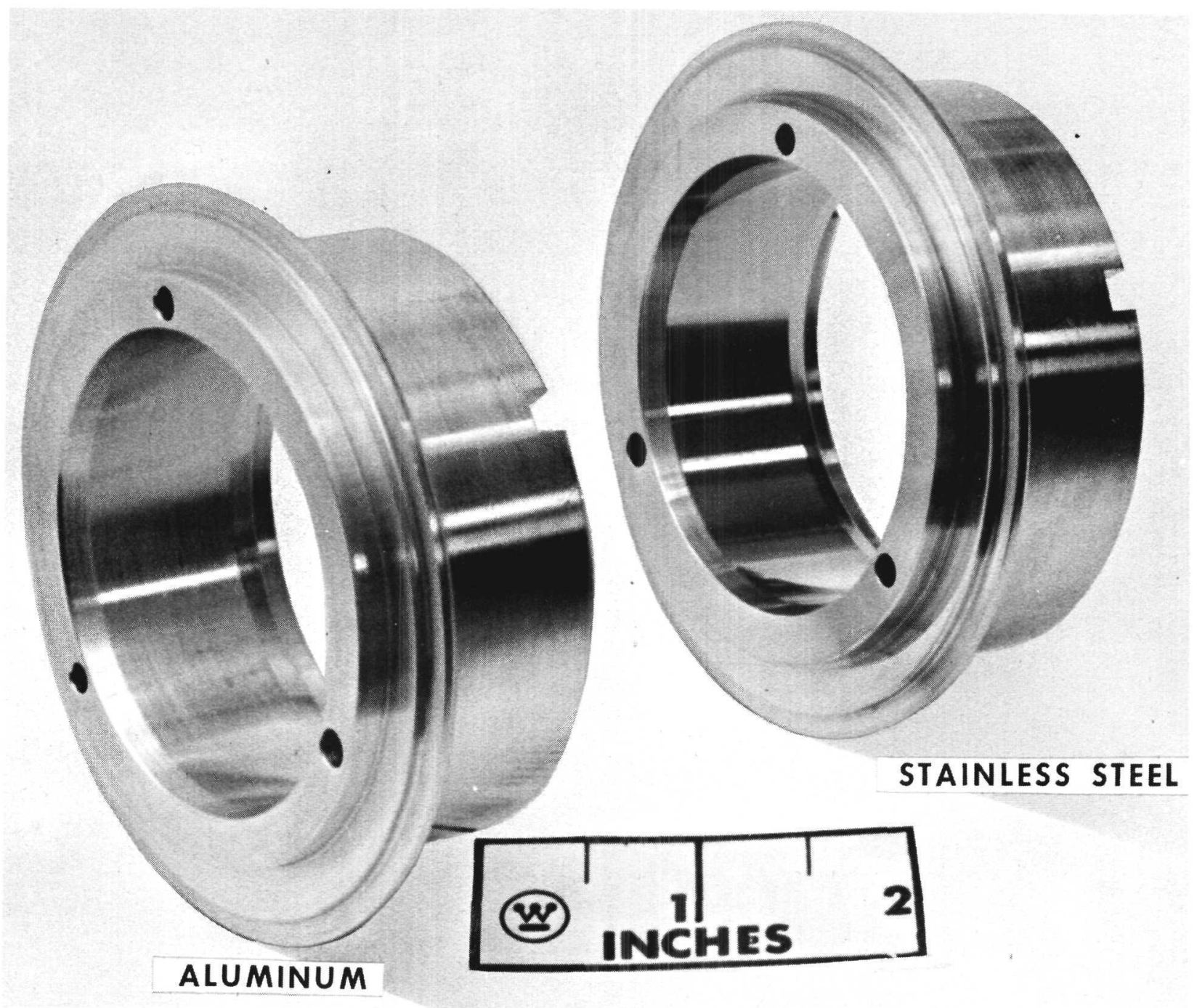

Figure 7

Marman Flanges 


\section{APPENDIX A}

\section{TEST RECORD SHEET}

\begin{tabular}{|c|c|}
\hline Test Record Sheet & Date \\
\hline \multirow[t]{3}{*}{ K1706773 } & $6 / 9 / 64$ \\
\hline & $6 / 10 / 64$ \\
\hline & $6 / 11 / 64$ \\
\hline K1706784 & $7 / 10 / 64$ \\
\hline K1706785 & $7 / 10 / 64$ \\
\hline K1706786 & $7 / 10 / 64$ \\
\hline K1706787 & $7 / 10 / 64$ \\
\hline K1706788 & $7 / 13 / 64$ \\
\hline K1706789 & $7 / 14 / 64$ \\
\hline$K 1535112$ & $7 / 23 / 64$ \\
\hline$K 1535114$ & $8 / 4 / 64$ \\
\hline \multirow[t]{2}{*}{ K1535115 } & $8 / 4 / 64$ \\
\hline & $8 / 6 / 64$ \\
\hline \multirow[t]{2}{*}{$K 1535121$} & $8 / 11 / 64$ \\
\hline & $8 / 13 / 64$ \\
\hline \multirow[t]{2}{*}{$K 1535126$} & $9 / 1 / 64$ \\
\hline & $9 / 8 / 64$ \\
\hline \multirow[t]{2}{*}{ K1535127 } & $9 / 9 / 64$ \\
\hline & $9 / 10 / 64$ \\
\hline K1535128 & $9 / 8 / 64$ \\
\hline \multirow[t]{3}{*}{ K1535129 } & $9 / 9 / 64$ \\
\hline & $9 / 10 / 64$ \\
\hline & $9 / 11 / 64$ \\
\hline
\end{tabular}




\section{APPENDIX B}

HARDWARE

The hardware anf fixtures were supplied by Reactor Mechanical Design. The following is a list of supplied parts.

\begin{tabular}{|c|c|c|}
\hline Quantity & Drawing & Item \\
\hline 1 & 945 C 479 HO1 Rev. - & Nut \\
\hline 1 & 963 B 921 HO1 Rev. - & Pin \\
\hline 3 & 963 B 320 HOl Rev. A & Bar-X Seal \\
\hline 1 & 945 C 702 H01 Rev. - & Ring \\
\hline 2 & $937 \mathrm{~J} 110$ Item 9 & Seal Block \\
\hline 1 & $937 \mathrm{~J} 110 \mathrm{ltem} 7$ & Locking Cup \\
\hline 1 & $937 \mathrm{~J} 110$ Item 8 & Locking Cup \\
\hline 2 & $937 \mathrm{~J} 110$ Item 10 & Adapter \\
\hline 1 & $937 \mathrm{~J} 110$ Item 11 & Spacer \\
\hline 1 & 937 J 110 Item 12 & Spacer \\
\hline 1 & $937 \mathrm{~J} 110$ Item 13 & Pin \\
\hline 1 & $937 \mathrm{~J} 110$ ltem 16 & Adapter \\
\hline 1 & $710 \mathrm{~J} 404$ Rev. - & Test Fixture \\
\hline 1 & 945 B 186 HO1 Rev. - & Washer \\
\hline 1 & 945 B 187 HO1 Rev. - & Pin \\
\hline 1 & 945 C 505 Rev. - & Coupling \\
\hline 1 & 946 C 105 HOI Rev. - & Gasket \\
\hline 50 & *Size 261 & "O" Ring \\
\hline
\end{tabular}




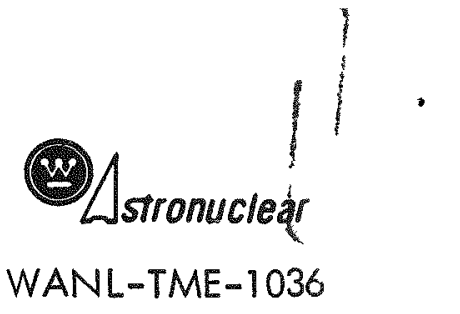

\begin{tabular}{lll} 
Quantity & Drawing & Item \\
\hline 50 & *Size 240 & "O" Ring \\
12 & $0.625-11$ UNC $\times 3.00 \mathrm{lg}$ & Bolt \\
8 & $0.500-13$ UNC $\times 2.25 \mathrm{lg}$ & Bolt
\end{tabular}

*Precision Rubber Products Company. Uniform size number. 